\title{
Soil and Leaf Mineral Element Contents in Mediterranean Vineyards: Bioaccumulation and Potential Soil Pollution
}

\author{
R. Jiménez-Ballesta ${ }^{\circledR} \cdot$ S. Bravo $\cdot$ J. A. Amorós • \\ C. Pérez-de-los-Reyes $\cdot$ J. García-Pradas $\cdot$ \\ M. Sanchez • F. J. García-Navarro
}

Received: 8 November 2021 / Accepted: 22 December 2021 / Published online: 6 January 2022

(C) The Author(s) 2021

\begin{abstract}
The study reported here concerns the geochemical distributions of macro- and trace elements (including potentially toxic elements, PTEs) in the vineyard soils of Alcubillas, which is one of the oldest, albeit not world-renowned, wine-growing areas in La Mancha (Central Spain). Soil and leaf samples were analyzed by X-ray fluorescence spectrometry to ascertain the levels of various elements in the soil and the plant. The potential toxicity of the elements was assessed with regard to the development of the vineyard. Despite the fact that fertilizers and pesticides are employed in the vineyards in this area, the results showed that the levels of trace elements in the soil samples did not exceed the reference values according the pedogeochemical values for the region and Spain. This finding suggests that the study area is not polluted, and therefore, there are hardly any traces of anthropogenic contamination. The Biological Absorption Coefficient (BAC) was calculated to assess the assimilation of various elements from the soil to the leaves, and differences were found in the
\end{abstract}

R. Jiménez-Ballesta $(\square)$

Department of Geology and Geochemistry, Autónoma University of Madrid, Madrid, Spain

e-mail: raimundo.jimenez@uam.es

S. Bravo · J. A. Amorós · C. Pérez-de-los-Reyes ·

J. García-Pradas · M. Sanchez · F. J. García-Navarro

University of Castilla-La Mancha, Higher Technical

School Agricultural Engineers of Ciudad Real,

Ciudad Real, Spain element absorption capacity of the vines. Some elements were not taken up by Vitis vinifera despite elements like $\mathrm{Zr}$ and $\mathrm{Rb}$ being present in relatively high concentrations in the soil. The production in these soils does not represent a threat to human health or the ecosystem, because the farmers in this area are extremely careful to preserve the environment and they only farm to achieve moderate yields of grapes per hectare.

Keywords Geochemistry of soil-grapevine · Mineral composition $\cdot$ PTEs $\cdot$ BAC $\cdot$ Risk assessment $\cdot$ Soil cultivation $\cdot$ Agroecosystem

\section{Introduction}

Soil is an important part of the natural environment and its effect on wine quality and grape composition is highly complex because it has an influence on mineral nutrition in the grapevine, the uptake of water, root depth, and rhizosphere temperature. In this respect, analysis of elements could be used (Greenough et al., 2005) since it is believed that these chemical elements present in the soil can be transferred to the plant and subsequently to the harvested grapes (Protano \& Rossi, 2014). The topic, however, is now being discussed further because it has not been demonstrated how these elements act on the sensory attributes of wines (Maltman, 2013). 
The concentration of some potential trace elements (PTEs) in soils, water, and vineyard agroecosystem is a key environmental quality indicator, as they are a possible source of PTEs to food chain leading to health risks. The vines can uptake potentially toxic elements from the soil and accumulate them in the roots or translocate them to the aerial parts. Accumulation of some elements in vineyard soils accelerates the elements uptake by vine, which could potentially affect vineyard and vine safety. Some elements pose a high environmental risk because of their long persistence in soil, water, and food chain. Elements occur naturally in soil but their concentrations can be increased by anthropic activities. Some of them, such as $\mathrm{Cu}, \mathrm{Zn}, \mathrm{Mo}$, Se, and $\mathrm{Fe}$, are essential for plants and animals, while others do not have any known benefits; most are non-essential element where some are toxic and carcinogenic such as lead, chromium, and cadmium (Abdu et al., 2011; Bravo et al., 2017). Other elements such as iron, copper, manganese, and zinc are plant nutrients in microdoses.

In viticulture, micronutrient deficiencies are corrected by the addition of trace elements that are essential for plant growth, e.g., $\mathrm{Cu}, \mathrm{Zn}, \mathrm{Fe}, \mathrm{Mn}$, and B. Treatment of plants with fungicides, pesticides, and herbicides also inputs chemicals into the vineyard soil. However, the presence of trace elements of natural origin in grapes and wine is mainly dependent on the mineralogical content of the soils, which are developed from various types of rocks. Contamination of soil, water, and crops with heavy metals may damage human health because they can accumulate in the trophic chain (Chen et al., 2015).

Trace elements, including potentially toxic elements (PTEs, Hooda, 2010), are found naturally in soils and they can also be introduced and accumulated due to anthropogenic influences in agricultural, urban, and industrial areas. The extensive use of fertilizers and fungicides (Geana et al., 2013; Kment et al., 2005; Komárek et al., 2010; Wightwick et al., 2013) leads to the accumulation of trace elements in vineyard soils and the bioavailability of such elements may be increased for plants. Other sources of trace elements include industrial pollution of sites (Geana et al., 2013; Moreno et al., 2007; Pohl, 2007). It is not surprising, therefore, that numerous studies on viticultural areas have focused on the identification of the main macro- and microelements in the soil, grapes, and wine (Geana et al., 2013; Huzum et al., 2012; Ungureanu et al., 2017).

The probability of anthropogenic contamination and the toxicological health risks associated with soil pollution can be evaluated by considering various indices (Mehr et al., 2017). Indeed, trace element data can be used, through predictive indices (such as the enrichment factor EF or Geoaccumulation Index, I-geo), to evaluate risks based on their total contents and toxicity (Gu et al., 2016; Muller, 1969). On the other hand, the bioaccumulation coefficient (BAC) provides information about the capacity of a plant to uptake nutrients and this parameter can be measured in any plant tissue (root, leaf, or fruit) (Kabata-Pendias, 2004).

Spain boasts the largest vineyard area in the world and the largest export volume, but also the lower the average sale price of liter globally; in addition, it lacks zoning policies, which makes Spain unique among traditionally wine-producing countries such as France, Italy, or Portugal (Alonso Gonzalez \& Parga Dans, 2019). Although terroir studies have generally focused on heavily populated regions, a few studies have been conducted in smaller rural locations. Therefore, it is necessary to conduct a geochemical investigation on the influence of soil on leaf and its potential contamination by impact of human activities. In this respect, the objectives of this study were to provide an overview of the contents of some major and trace elements (including PTEs) in vineyard soils in a small Mediterranean and traditional rural location, namely Alcubillas (La Mancha, Central Spain), with special attention paid to those elements that under particular environmental circumstances may become toxic. The specific goals were (i) to provide a database for the studied macro- and microelements, (ii) to establish an ecological risk assessment for some PTEs in order to contribute to sustainable management of this agricultural area, and (iii) to determine if certain elements are present in significant quantities in grapevine leaves in relation to soil composition.

We expect that this study could contribute to the understanding of the potential accumulation of elements, with emphasis on PTEs, in soils under vineyards and that the application of the regional threshold value can provide a more reliable assessment of the soil contamination. 


\section{Material and Methods}

\subsection{Study Area}

The study area Alcubillas is in the Castilla-La Mancha Community in Central Spain (Fig. 1). The coordinates of this site are $38^{\circ} 45^{\prime} 7^{\prime \prime} \mathrm{N}$ and $3^{\circ} 8^{\prime} 5^{\prime} \mathrm{W}$ and the area is 4768 ha. The main crops that are cultivated in Alcubillas are vines, olive trees, and cereals. There are also some small plots dedicated to orchards.

One of the main physiographic features is a virtually flat and karstified surface that is interrupted by residual reliefs in the form of inselberg and an alluvial plain. The major parent materials are calcareous sediments, limestones (with signs of karstification, as evidenced by the appearance of numerous "dolinas"), clay sediments of fluvial character, and quartzite sandstones (in some cases slates) in residual surfaces of the Paleozoic era. At this site, the majority of the soils are Alfisols, Inceptisols, and Entisols according to Soil Taxonomy (Soil Survey Staff, 2014) and Luvisols, Calcisols, Cambisols, Regosols, and Leptsols according to IUSS Working Group WRB (2015). The dominant formation is constituted by Red soils (Alfisols) with calcic or petrocalcic horizons (JiménezBallesta et al., 2020).

\subsection{Sampling and Laboratory Methods}

After consecutive inspections of the studied area and investigation of the area's map, sampling was carried out during July 2018. Soil samples from 10 profiles and 12 superficial horizons were collected. The sampling locations were selected from different geomorphological sites and vineyard types. Given that the majority of the active vine roots are located at a depth of $20-80 \mathrm{~cm}$, the samples were taken from the Ap and Bt or Bw horizons. The soil samples were kept in a plastic bag and preserved in the laboratory until chemical analysis. Leaf samples were collected along with the soil on which the plants were growing. Leaf samples were taken before harvest (following Bravo et al., 2017 procedure) from six plants located around each profile: vines that have received the same fertilizer program. The leaf samples were dried in the laboratory around 7 days at $30{ }^{\circ} \mathrm{C}$. Subsequently, the samples were ground in an agate mortar until the material had a diameter of less than $43 \mathrm{~mm}$.

The samples were transferred to the laboratory for further analysis. It is worth mentioning that the exact location of each sample was recorded using handheld GPS. The soil samples were air-dried naturally and sieved through a $2-\mathrm{mm}$ sieve to remove the coarse fraction. The remaining fine-earth fraction was homogenized before chemical analysis was carried out.

The contents of major and trace elements $(\mathrm{Na}, \mathrm{Mg}$, $\mathrm{Al}, \mathrm{Si}, \mathrm{P}, \mathrm{S}, \mathrm{K}, \mathrm{Ca}, \mathrm{Fe}, \mathrm{Mn}, \mathrm{Ti}, \mathrm{Ba}, \mathrm{Sr}, \mathrm{V}, \mathrm{Cr}, \mathrm{Ce}, \mathrm{Rb}$, $\mathrm{Ni}, \mathrm{Zn}, \mathrm{Nd}, \mathrm{Pb}, \mathrm{Nb}, \mathrm{Co}, \mathrm{Cs}, \mathrm{Ga}, \mathrm{La}, \mathrm{Y}, \mathrm{Zr}, \mathrm{Sc}$, Th, U, $\mathrm{Sn}, \mathrm{Cu}, \mathrm{As}, \mathrm{Mo}, \mathrm{Ta}, \mathrm{Hf}$, and $\mathrm{W}$ ) in the soil and leaf samples were determined by X-ray fluorescence spectroscopy (XRF) using a Philips PW 2404 spectrophotometer with a maximum power of $4 \mathrm{~kW}$ (set of crystal analyzers for LiF220, LiF200, Ge, PET, and PX1, flow detector, and twinkle detector). This analytical technique has been validated for solid matrices such as sediment (Stosnach and Mages, 2009; Pessanha et al., 2010). Quality control was ensured by duplicate
Fig. 1 Geographical location of the research study area. Source: own elaboration

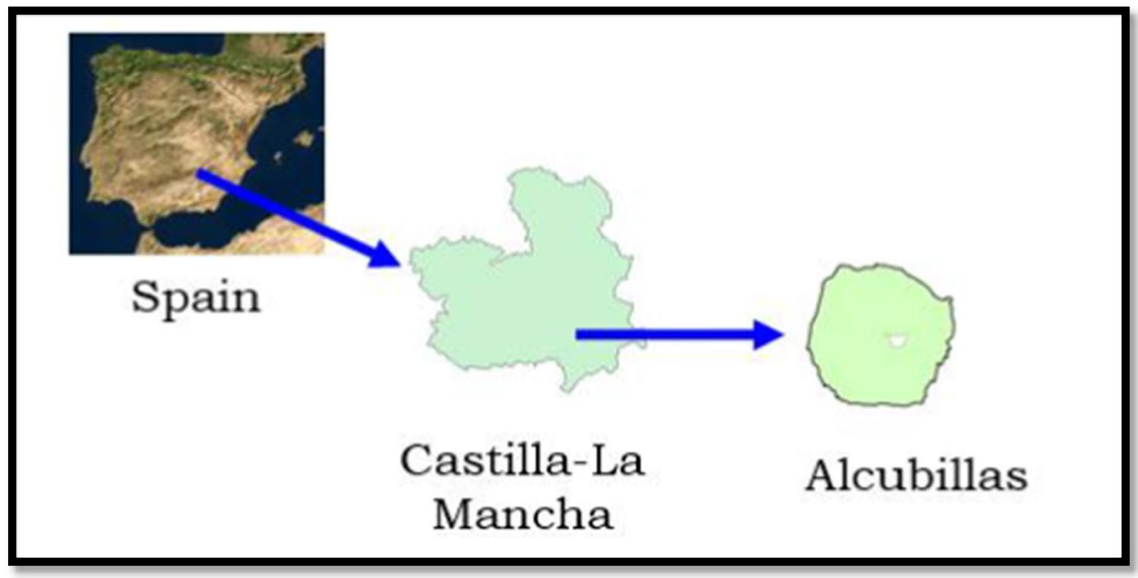


analysis of certified reference samples (BCR 62, SMR 1573A, SMR 1515).

\subsection{Statistical Analysis}

The data were analyzed using Microsoft Office Excel 2018 and the software Statistical Package for Social Science (SPSS 24.0 for Windows, SPSS Inc., IL, U.S.A.), both under institutional licenses for the University of Castilla-La Mancha (Spain).

\subsection{Pollution Indices: Geoaccumulation Index (I-geo)}

To investigate the soil contamination, the so-called I-geo was employed in the current research paper. This was originally defined by Muller (1969) and is obtained using the formula:

$$
I_{\text {geo }}=\log _{2} \frac{C_{n}}{1.5 B_{n}}
$$

where $C_{n}$ denotes the measured value and $B_{n}$ is the geochemical background of the site. Throughout this paper, the term "background" will refer to indicate the concentration of a substance reflecting natural processes uninfluenced by human activities as suggested by Reimann \& Garrett (2005). The factor 1.5 is applied to control variations in $B_{n}$ values caused by anthropogenic influences. The I-geo was defined into seven classes (Table 1) by Buccolieri et al. (2006).

\subsection{Biological Absorption Coefficient (BAC)}

The BAC is the ratio between the plant and soil concentrations of each element. BAC o bioconcentration

Table 1 Categories for the Geoaccumulation Index (I-geo), by Buccolieri et al. (2006)

\begin{tabular}{ll}
\hline Value & Classification \\
\hline I-geo $\leq 0$ & Uncontaminated \\
$0<$ I-geo $<1$ & Uncontaminated to moderately contaminated \\
$1<$ I-geo $<2$ & Moderately contaminated \\
$2<$ I-geo $<3$ & Moderately to strongly contaminated \\
$3<$ I-geo $<4$ & Strongly contaminated \\
$4<$ I-geo $<5$ & Strongly to extremely contaminated \\
I-geo $\geq 5$ & Extremely contaminated \\
\hline
\end{tabular}

factor $(\mathrm{BCF})$ is determined as a ratio of element in plant parts/edible parts to that present in the soils where a particular crop grown/obtained:

In this study, the concentration in the leaf was used.

$\mathrm{BAC}=\frac{[\text { leaf }]}{[\text { soil }]}$

Indeed, the BAC o BCF explains the transfer and bioavailability of elements from soil to plants or plants' edible parts, helping to explain bioavailability and bioconcentration of metals in farming system (Lugwisha, 2016). The BAC of above 1 indicates higher uptake of element in crop/plant compared to that in soil while BAC of less than 1 indicates more element concentration in soil than those taken up by plants.

\section{Results and Discussion}

\subsection{Macroelement Contents in Soils}

The results of macroelement measurements are summarized as mean, standard deviation (SD), minimum, and maximum values (Table 2).

The vineyard soils from the Alcubillas site showed a heterogeneous concentration for the elemental composition (Table 2), with $\mathrm{Si}$ and $\mathrm{Ca}$ being the most abundant major elements followed by $\mathrm{Al}$, influenced by the parent rock. The average soil contents in Ca were $134.4 \mathrm{~g} \mathrm{~kg}^{-1}$ in topsoil (Ap horizons) and $161.6 \mathrm{~g} \mathrm{~kg}^{-1}$ in subsoil (B horizons). These values (that highlight the calcaric character of the studied soils) are higher than the global average $\left(15 \mathrm{~g} \mathrm{~kg}^{-1}\right.$, Kabata Pendias, 2011); in some cases, the Ca content even reached values up to $412.7 \mathrm{~g} \mathrm{~kg}^{-1}$. It is worth pointing out that there are wine areas in the world with similar contents in $\mathrm{Ca}$ and many of these are highly appreciated for their wines. This is the case, for example, in the Champagne and Burgundy regions in France, Tuscany in Italy, and La Rioja in Spain.

Iron $(\mathrm{Fe})$ and potassium $(\mathrm{K})$ are present at lower levels that $\mathrm{Ca}$. Iron-the average content of which in both horizons was $32.3 \mathrm{~g} \mathrm{~kg}^{-1}$ - is necessary for the formation of chlorophyll, the respiration process of plants, and the formation of certain proteins. The value for sulfur (S) obtained in the study area 
Table 2 Contents and main statistics for mineral elements (expressed in $\mathrm{g}$ $\mathrm{kg}^{-1}$ ) analyzed in this study

Max, maximum; Min, minimum; $S D$, statistical deviation

\begin{tabular}{lllllllllllll}
\hline Soil & & $\begin{array}{l}\mathrm{Na} \\
\mathrm{g} \mathrm{kg}^{-1}\end{array}$ & $\mathrm{Mg}$ & $\mathrm{Al}$ & $\mathrm{Si}$ & $\mathrm{P}$ & $\mathrm{S}$ & $\mathrm{K}$ & $\mathrm{Ca}$ & $\mathrm{Fe}$ & $\mathrm{Mn}$ & $\mathrm{Ti}$ \\
\hline Ap & Mean & 10 & 12.9 & 68.9 & 167.6 & 0.8 & 0.4 & 37.9 & 134.4 & 32.3 & 0.7 & 6.0 \\
& Max & 1.4 & 14.9 & 86.6 & 204.3 & 1.4 & 0.6 & 196.0 & 247.7 & 42.9 & 1.4 & 13.6 \\
& Min & 0.5 & 9.9 & 42.2 & 115.9 & 0.6 & 0.4 & 12.5 & 83.4 & 22.5 & 0.4 & 0.3 \\
& SD & 0.2 & 1.6 & 11.5 & 25.6 & 0.2 & 0.0 & 50.1 & 46.0 & 5.2 & 0.2 & 4.5 \\
\multirow{4}{*}{ Bt or Bw } & Mean & 0.9 & 12.4 & 67.3 & 156.9 & 0.5 & 0.3 & 20.7 & 161.6 & 32.2 & 0.6 & 5.8 \\
& Max & 1.5 & 16.1 & 87.9 & 201.3 & 0.9 & 0.5 & 28.8 & 412.7 & 43.1 & 1.5 & 14.0 \\
& Min & 0.5 & 6.5 & 39.0 & 87.9 & 0.3 & 0.2 & 11.2 & 81.0 & 20.8 & 0.2 & 0.4 \\
& SD & 0.2 & 2.5 & 14.4 & 33.7 & 0.1 & 0.0 & 5.3 & 94.2 & 6.1 & 0.3 & 4.7 \\
& & & & & & & & & & & &
\end{tabular}

is $0.6 \mathrm{~g} \mathrm{~kg}^{-1}$, a value below the average world background level (0.70 $\mathrm{g} \mathrm{kg}^{-1}$, Kabata-Pendias, 2011).

The variances in the $\mathrm{Si}$ and $\mathrm{Ca}$ values are very large, while $\mathrm{Na}, \mathrm{Mg}, \mathrm{S}, \mathrm{P}$, and $\mathrm{Mn}$ showed low variance. These variations can be explained as being the result of soil evolution and, to a lesser extent, ploughing and agricultural practices, as reported by Mîrlean et al. (2007). Manganese (Mn) concentrations varied very little in the soils in the study area (between 0.7 and $0.6 \mathrm{~g} \mathrm{~kg}^{-1}$ ).

\subsection{Trace Element Contents in Soils}

The results of microelemental measurements are summarized as mean, standard deviation (SD), minimum, and maximum values (Table 3 ).

Table 3 Descriptive statistics of microelement contents in soils and obtained I-geo values

\begin{tabular}{|c|c|c|c|c|c|c|c|c|c|c|c|c|c|c|}
\hline Soil & & $\begin{array}{l}\mathrm{Ba} \\
\mathrm{mg} \mathrm{kg}^{-1}\end{array}$ & $\mathrm{Sr}$ & V & $\mathrm{Cr}$ & $\mathrm{Ce}$ & $\mathrm{Rb}$ & $\mathrm{Ni}$ & $\mathrm{Zn}$ & $\mathrm{Nd}$ & $\mathrm{Pb}$ & $\mathrm{Nb}$ & $\mathrm{Co}$ & Cs \\
\hline \multirow[t]{4}{*}{ Ap } & Mean & 323.7 & 124.4 & 72.5 & 51.4 & 57.9 & 83.9 & 34.7 & 47.4 & 27.9 & 21.9 & 14.2 & 10.4 & 9.3 \\
\hline & Max & 446.4 & 152.8 & 99.0 & 71.0 & 85.3 & 118.9 & 51.5 & 72.3 & 43.1 & 31.6 & 18.2 & 13.6 & 15.9 \\
\hline & Min & 177.4 & 101.6 & 45.6 & 29.9 & 41.6 & 40.4 & 20.6 & 28.5 & 19.9 & 13.3 & 9.6 & 7.2 & 2.1 \\
\hline & SD & 69.9 & 14.2 & 15.3 & 10.8 & 12.6 & 20.9 & 9.1 & 12.3 & 6.4 & 6.0 & 2.3 & 2.1 & 4.5 \\
\hline \multirow[t]{4}{*}{$\mathrm{Bt}$ or $\mathrm{Bw}$} & Mean & 315.4 & 125.0 & 70.0 & 50.0 & 52.6 & 81.9 & 33.9 & 43.6 & 25.5 & 20.2 & 13.9 & 10.4 & 16.7 \\
\hline & Max & 447.6 & 152.1 & 104.8 & 70.9 & 85.1 & 119.5 & 50.9 & 68.7 & 40.2 & 31.4 & 18.5 & 15.2 & 94.0 \\
\hline & Min & 137.8 & 91.1 & 34.8 & 25.5 & 20.5 & 34.0 & 13.7 & 20.1 & 13.8 & 7.4 & 8.6 & 6.1 & 0.7 \\
\hline & SD & 90.5 & 15.8 & 20.6 & 13.4 & 19.4 & 26.1 & 10.9 & 15.0 & 8.0 & 7.5 & 2.9 & 2.7 & 24.9 \\
\hline I-geo & & -0.8 & -2.1 & -0.0 & -0.6 & -0.6 & -0.6 & 0.4 & -0.1 & -0.2 & -0.4 & -0.0 & 0.2 & -0.3 \\
\hline Soil & & $\begin{array}{l}\mathrm{Ga} \\
\mathrm{mg} \mathrm{kg}^{-1}\end{array}$ & $\mathrm{La}$ & $\mathrm{Y}$ & $\mathrm{Zr}$ & $\mathrm{Sc}$ & Th & $\mathrm{U}$ & $\mathrm{Cu}$ & Mo & $\mathrm{Ta}$ & Hf & W & \\
\hline \multirow[t]{4}{*}{ Ap } & Mean & 13.7 & 30.2 & 22.3 & 214.4 & 15.5 & 8.8 & 2.2 & 25.0 & 0.9 & 1.3 & 5.5 & 1.6 & \\
\hline & Max & 18.7 & 48.3 & 31.5 & 287.1 & 18.5 & 12.3 & 3.2 & 32.4 & 1.3 & 2.2 & 8.2 & 3.3 & \\
\hline & Min & 6.7 & 23.6 & 14.5 & 128.1 & 11.9 & 4.5 & 0.4 & 17.4 & 0.5 & 0.2 & 2.8 & 0.1 & \\
\hline & SD & 3.1 & 7.2 & 5.0 & 49.4 & 1.7 & 2.0 & 0.6 & 4.0 & 0.2 & 0.6 & 1.4 & 0.9 & \\
\hline \multirow[t]{4}{*}{$\mathrm{Bt}$ or $\mathrm{Bw}$} & Mean & 13.4 & 27.2 & 21.1 & 201.5 & 15.0 & 8.1 & 2.5 & 23.6 & 1.0 & 1.1 & 4.7 & 1.3 & \\
\hline & Max & 18.9 & 45.7 & 31.4 & 293.5 & 19.1 & 12.5 & 3.2 & 30.3 & 1.3 & 3.0 & 6.7 & 2.9 & \\
\hline & Min & 6.6 & 9.2 & 11.2 & 57.3 & 8.3 & 2.5 & 1.5 & 12.4 & 0.7 & 0.3 & 1.3 & 0.3 & \\
\hline & SD & 3.6 & 10.3 & 6.1 & 60.1 & 2.8 & 2.6 & 0.5 & 5.0 & 0.1 & 0.9 & 1.4 & 0.8 & \\
\hline I-geo & & -0.3 & -0.3 & -0.3 & -0.2 & -1.1 & -0.7 & -1.8 & -0.2 & -0.2 & -1.2 & -0.4 & -2.8 & \\
\hline
\end{tabular}

Max, maximum; Min, minimum; SD, statistical deviation, I-geo 
The data reported in Table 3 allow some general observations to be made. These data and the behavior of some elements are discussed below.

\subsection{Copper $(\mathrm{Cu})$ and Zinc $(\mathrm{Zn})$}

Copper is also one of the most widely studied elements in wine-growing regions because the treatment and prevention of vine downy mildew is commonly carried out using the Bordeaux mixture $\left(\mathrm{Ca}(\mathrm{OH})_{2}+\mathrm{CuSO}_{4}\right)$. However, copper becomes toxic to plants and some micro-organisms when it is present at high levels in soils as it disrupts nutrientcycling and inhibits the mineralization of essential nutrients. Accumulation of copper in soils is mainly due to anthropogenic origin, such as mining or industrial activities. Agricultural use of products containing copper is also common, especially in pesticides applied in vineyards and orchards (Fishel, 2014).

In the soils under discussion here, copper was present in an acceptable medium level (Table 3), i.e., between $25.0 \mathrm{mg} \mathrm{kg}^{-1}$ (topsoil) and $23.7 \mathrm{mg} \mathrm{kg}^{-1}$ (subsoil). The world average level in soil is $30 \mathrm{mg} \mathrm{kg}^{-1}$ (from 2 to $250 \mathrm{mg} \mathrm{kg}^{-1}$, Adriano, 2001), and the normal variation in soils is between $5 \mathrm{mg} \mathrm{kg}^{-1}$ and $50 \mathrm{mg} \mathrm{kg}^{-1}$ (Bloemen et al., 1995). A mean value of $35.4 \mathrm{mg} \mathrm{kg}^{-1}$ has been determined in Spain (Peris et al., 2007), $24 \mathrm{mg} \mathrm{kg}^{-1}$ (from 1 to $111 \mathrm{mg} \mathrm{kg}^{-1}$ ) in Portugal (Reis et al., 2007), $227 \mathrm{mg} \mathrm{kg}^{-1}$ in France for the deep horizon (Chopin et al., 2008), while in Brazil, the content is in the range from $50.1 \mathrm{mg} \mathrm{kg}^{-1}$ (20 years) to $2197 \mathrm{mg} \mathrm{kg}^{-1}$ (100 years) (Mîrlean et al., 2007). The pedogeochemical baseline level for Castilla-La Mancha is $10.3 \mathrm{mg} \mathrm{kg}^{-1}$ (Jiménez-Ballesta et al., 2010).

Zinc is an essential element for both plants and humans, but it is toxic in excess amounts (Tóth et al., 2016). The average contents in $\mathrm{Zn}$ (Table 3) are $47.4 \mathrm{mg} \mathrm{kg}^{-1}$ (topsoil) and $43.6 \mathrm{mg} \mathrm{kg}^{-1}$ (subsoil). According to other authors, the values for $\mathrm{Zn}$ range between $10 \mathrm{mg} \mathrm{kg}^{-1}$ and $300 \mathrm{mg} \mathrm{kg}^{-1}$ (Adriano, 2001), with a world soil average of $50 \mathrm{mg} \mathrm{kg}^{-1}$, so contamination is not evident for this element. In Castellon (Spain), the average value is $76.8 \mathrm{mg} \mathrm{kg}^{-1}$ (Peris et al., 2007); in the Champagne region of France (Chopin et al., 2008), the values range from $318 \mathrm{mg} \mathrm{kg}^{-1}$ in the topsoil to $208 \mathrm{mg} \mathrm{kg}^{-1}$ in the deep horizon, with $75 \mathrm{mg} \mathrm{kg}^{-1}$ as median; and in Portugal (Reis et al., 2007), a minimum value of $14 \mathrm{mg} \mathrm{kg}^{-1}$ and a maximum value of $344 \mathrm{mg} \mathrm{kg}^{-1}$ were determined for vineyard areas. Finally, the pedogeochemical baseline level for Castilla-La Mancha (Central Spain) is $35.7 \mathrm{mg} \mathrm{kg}^{-1}$ (Jiménez-Ballesta et al., 2010). Increased concentrations of $\mathrm{Zn}$ and $\mathrm{Cu}$ in soils under the long-term production of grapevine have been recorded in numerous studies (Romic \& Romic, 2003; Fishel, 2014; Tóth et al., 2016).

\subsection{Lead $(\mathrm{Pb})$, Cobalt (Co), and Chromium (Cr)}

Exposure to lead occurs mainly through the food chain, although ingestion of soil and dust can also be an important contributor. In the vineyard soils studied, lead $(\mathrm{Pb})$ has average values (Table 3) of $21.9 \mathrm{mg} \mathrm{kg}^{-1}$ in topsoil and $20.2 \mathrm{mg} \mathrm{kg}^{-1}$ in subsoil. In some cases, moderately high $\mathrm{Pb}$ levels $\left(31.6 \mathrm{mg} \mathrm{kg}^{-1}\right)$ are detected in some soils when compared to the pedogeochemical baseline levels for Castilla-La Mancha (19.3 mg kg-1, JiménezBallesta et al., 2010). This level is probably caused by the mechanized equipment used for works carried out in the vineyard. However, these values are still far below the total mean contents of other regions. For example, the lead content in Castellon, Spain, is $56.1 \mathrm{mg} \mathrm{kg}^{-1}$ (Peris et al., 2007), in the Champagne region of France, $\mathrm{Pb}$ ranges from 76 (deep horizon) to $141 \mathrm{mg} \mathrm{kg}^{-1}$ (topsoil) (Chopin et al., 2008), and, in the case of the soils from Brestnik village (Bulgaria), values range from $72.6 \mathrm{mg} \mathrm{kg}^{-1}$ for a depth of $0-10 \mathrm{~cm}$ to $61.4 \mathrm{mg} \mathrm{kg}^{-1}$ (Huzum et al., 2012).

In the present study, the chromium $(\mathrm{Cr})$ content is in the range between 71.0 and $29.9 \mathrm{mg} \mathrm{kg}^{-1}$ (Table 3), with an average of $51.4 \mathrm{mg} \mathrm{kg}^{-1}$, in top horizons, whereas in the subsoil, the values range between 70.9 and $25.5 \mathrm{mg} \mathrm{kg}^{-1}$, with an average of $50.0 \mathrm{mg} \mathrm{kg}$. The chromium contents in soils worldwide differ greatly, i.e., in the range from 7 to $2221 \mathrm{mg} \mathrm{kg}^{-1}$ (McBride, 1994), and this depends mostly on the parent material and soil mineralogy. Mîrlean et al. (2007) suggested a variation between 8.2 (young plantation) and $77.9 \mathrm{mg} \mathrm{kg}^{-1}$. In Portugal, the $\mathrm{Cr}$ content has an average of $31 \mathrm{mg} \mathrm{kg}^{-1}$ (from a minimum of 3 to a maximum value of $243 \mathrm{mg} \mathrm{kg}^{-1}$ ) (Reis et al., 2007), while the values for some areas in Spain are quite similar, with a total mean content of $32.2 \mathrm{mg} \mathrm{kg}^{-1}$ (Peris et al., 2007). With some exceptions, the chromium concentrations did not exceed the 
pedogeochemical baseline value for soils of CastillaLa Mancha (Jiménez-Ballesta et al., 2010).

Cobalt is an element which is essential to human health (e.g., it is part of vitamin B12), but which in excess amounts can cause serious effects to the lungs and heart (ATSDR, 2004a). It is worth noting that the transfer potential from soil to the edible parts of plants is rather low (Luo et al., 2010). The average cobalt (Co) content is near to $10.5 \mathrm{mg} \mathrm{kg}^{-1}$ (Table 3) for both topsoil and subsoil, with values slightly higher than for the soils of Castilla-La Mancha $\left(5.8 \mathrm{mg} \mathrm{kg}^{-1}\right.$, Jiménez-Ballesta et al., 2010). Cobalt is an element that is essential to human health but excess amounts can cause detrimental effects, although the transfer potential from soil to the edible parts of plants is rather low (Luo et al., 2010).

Nickel in soil, like most other heavy metals, may be of either natural or anthropogenic origin. The total average nickel (Ni) contents (Table 3) in the topsoil and subsoil of Alcubillas are similar (34.7 vs. $33.9 \mathrm{mg} \mathrm{kg}^{-1}$, respectively). In terms of $\mathrm{Ni}$ values, a total mean content of $19.9 \mathrm{mg} \mathrm{kg}^{-1}$ was reported for the Castellon area of Spain (Peris et al., 2007) and a mean value of $28 \mathrm{mg} \mathrm{kg}^{-1}$ (with a minimum of $2 \mathrm{mg} \mathrm{kg}^{-1}$ and a maximum of $539 \mathrm{mg} \mathrm{kg}^{-1}$ ) was found in the Douro basin, Portugal (Reis et al., 2007). The levels of Ni in Alcubillas are slightly higher than the current Castilla-La Mancha pedogeochemical reference value $\left(16.9 \mathrm{mg} \mathrm{kg}^{-1}\right)$.

\subsection{Strontium (Sr) and Molybdenum (Mo)}

The contents of strontium in the surface and subsurface horizons are $125.9 \mathrm{mg} \mathrm{kg}^{-1}$ (Table 3). The mean worldwide background concentration for $\mathrm{Sr}$ in soil is $147.9 \mathrm{mg} \mathrm{kg}^{-1}$ (Kabata-Pendias, 2011) and in Castilla-La Mancha, it is $380.0 \mathrm{mg} \mathrm{kg}^{-1}$, although in this Community, values of up to $3384.9 \mathrm{mg} \mathrm{kg}^{-1}$ have been found in soils on gypsum or gypsum marls (Conde et al., 2008). Alcubillas is an active agricultural area and therefore, the levels determined cannot be attributed to the use of soil amendments (e.g., phosphorus fertilizers). Various anthropogenic activities, including the application of fertilizers, the generation of nuclear power, and the burning of coal to generate power, have led to increased levels of strontium (Sr) in soil (Burger \& Lichtscheidl, 2019). The great potential for the accumulation of $\mathrm{Sr}$ in plants and animals can pose serious environmental and human health hazards, which include cancers and disorders of the nervous system (Burger \& Lichtscheidl, 2019). The average $\mathrm{Sr}$ contents in some materials commonly used in agriculture include $80.9 \mathrm{mg} \mathrm{kg}^{-1}$ in manure, $75.9 \mathrm{mg} \mathrm{kg}^{-1}$ in sewage sludge, and $270.9 \mathrm{mg} \mathrm{kg}^{-1}$ in industrial sludge (Munthali et al., 2015). Phosphate fertilizers can also act as a local source of $\mathrm{Sr}$ contamination in soil. It is worth highlighting that all $\mathrm{Sr}$ concentrations for all soil types in this study were below the background value, thus indicating that there is no $\mathrm{Sr}$ pollution in the study area.

Molybdenum is involved as a micronutrient anion in various physiological and enzymatic processes in plants (Mishra et al., 2006) and humans (Schwarz \& Belaidi, 2013). Sr is able to affect the health of plants and animals because in high concentrations, it is a potentially toxic metal (Evans \& Barabash, 2010). The average Mo content in the surface soils of Alcubillas was $0.9 \mathrm{mg} \mathrm{kg}^{-1}$ and in the subsurface soils, it was $1.0 \mathrm{mg} \mathrm{kg}^{-1}$ (Table 3), with a maximum level of $1.3 \mathrm{mg} \mathrm{kg}^{-1}$. In comparison to the pedogeochemical references for Castilla-La Mancha, these values are lower or similar and they are also lower than the mean background content of Mo in surface soils as a worldwide average $\left(1.1 \mathrm{mg} \mathrm{kg}^{-1}\right.$, Kabata-Pendias, 2011).

\subsection{Ecological Risk Assessment}

Many studies have been conducted recently regarding the pollution of the vineyard soil with toxic elements (Gallo et al., 2018; Milićević et al., 2018; Beygi \& Jalali, 2019; Pham et al., 2021). The pollution index (I-geo) provides a useful tool to evaluate potential environmental contamination. On considering the I-geo (Table 3) values, it can be observed that all values fall in the 0 class, which indicates the absence of contamination, i.e., almost all of the elements are of natural origin or from natural weathering processes. Only some points appearing with $\mathrm{Cu}, \mathrm{Ni}$, and $\mathrm{Co}$ fall into the class 1 category, and these elements are therefore influenced slightly by human activity.

\subsection{Trace Element Contents in Leaves: Soil/Leaf Ratios}

A high level of PTEs in farming areas may accelerate the uptake of PTEs in plant systems and grains (Liu et al., 2015; Zhou et al., 2014). Soil plays a 
central role in vine and wine safety. The vines like other plants require trace elements in their growth and metabolism (John et al., 2019; Kabata-Pendias \& Szteke, 2015). Deficiency as well as excess levels of trace elements in soils impairs crop growth and reduces yield, thereby disrupting the entire food chain (Bello et al., 2018). Trace elements are generally considered important for crop and animal production as well as for human needs (Hooda, 2010).

For primary production through photosynthesis, in addition to water and carbon dioxide, plants require some inorganic mineral nutrients that are taken up through the root system. In this process, elements are transferred from soil to plant and the leaf mineral composition should reflect the complex interaction between Vitis vinifera and the local soil composition, since it is one of main factors that limits plant productivity and quality.

Soil contamination with PTEs has become a growing global environmental and human health crisis (Jiménez-Ballesta et al., 2017, Rinklebe et al., 2019). To address this topic, terms such as bioaccessibility, bioavailability, and bioaccumulation are used. Bioavailability is a complex issue that includes metal species that are bioaccessible and are absorbed or adsorbed by an organism. This term is related to several soil processes and may be largely determined by soil characteristics, and is essential to determine if heavy metals present in soil may pose hazards to humans and the environment, while biomagnification is expressed as the ratio of the concentration in the organisms of the higher trophic level to the concentration in the organisms of the lower trophic level. But perhaps the most used term in viticulture is bioaccumulation, defined as the net accumulation of a metal in a tissue of interest or a whole organism that results from exposure. The Biological Absorption Coefficient (BAC) is the bioaccumulation of a given element and this is the ratio between the leaf/soil concentrations (Kabatha-Pendias, 2003). The BAC values are listed in Table 4.

The modified Kabata-Pendias BAC classification (2001) was used here to classify the major elements accumulated in the vine leaf. The elements $\mathrm{Ca}$, $\mathrm{K}, \mathrm{Mg}$, and $\mathrm{S}$ had high BAC values (greater than 1), whereas $\mathrm{Sr}$ and $\mathrm{Zn}$ had medium BAC values (between 0.4 and 0.7 ) and $\mathrm{Ba}, \mathrm{Pb}$, and $\mathrm{Cu}$ had low values (between 0.4 and 0.10 ). Finally, $\mathrm{V}$ and $\mathrm{Cr}$ had very low values $(<0.1)$. The $\mathrm{BAC}$ value obtained for $\mathrm{Sr}$
Table 4 Biological Absorption Coefficient (BAC) of some elements and their comparison with other studies in CastillaLa Mancha. *Amorós et al. (2013); Bravo et al. (2017)

\begin{tabular}{lll}
\hline Element & BAC (leaf/soil) & BAC (leaf/soil)* \\
\hline $\mathrm{Ba}$ & 0.14 & 0.26 \\
$\mathrm{Sr}$ & 0.56 & 0.28 \\
$\mathrm{~V}$ & 0.06 & 0.16 \\
$\mathrm{Cr}$ & 0.07 & 0.17 \\
$\mathrm{Zn}$ & 0.70 & 0.37 \\
$\mathrm{~Pb}$ & 0.12 & 0.15 \\
$\mathrm{Cu}$ & 0.19 & 1.86 \\
\hline
\end{tabular}

in this study is similar to those reported in the scientific literature (Kabata-Pendias \& Sadurski, 2004). If we compare the results obtained in other studies carried out in Castilla-La Mancha (Amorós et al., 2013; Bravo et al., 2017), it can be observed that the values for $\mathrm{Sr}$ and $\mathrm{Zn}$ are higher ( 0.56 vs. 0.28 and 0.7 vs. 0.37 , respectively); the values for $\mathrm{Ba}, \mathrm{V}, \mathrm{Cr}$, and $\mathrm{Cu}$ are lower ( 0.14 vs. 0.26 ; 0.06 vs. $0.16 ; 0.07$ vs. 0.17 and 0.19 vs. 1.86 , respectively), while the value of $\mathrm{Pb}$ is similar (0.12 vs. 0.15$)$.

The relationship between the concentrations of major and trace elements studied in soils and leaves from grapevine cultivars of Alcubillas is represented in Fig. 2. It can be seen that the higher the soil contents in $\mathrm{Sr}, \mathrm{Pb}$, and $\mathrm{Cr}$, the higher the contents of the same elements incorporated in the leaves. Amorós et al. (2012) found a positive correlation between the amount of $\mathrm{Sr}$ in the soil and that in the leaf and grape. A similar trend was observed for $\mathrm{Cu}, \mathrm{Zn}$, and, to a lesser extent, $\mathrm{Ba}$, but less markedly than for the previous elements. Finally, the content of $\mathrm{V}$ in the leaf decreases as the content in the soil increases.

All of these data provide relevant information that could help to ascertain the nutritional status of the plant. Nevertheless, significant correlations were not found in this survey; the uptake of elements in grapevine can be influenced by soil, climate, geographic origin, and rootstock type.

The elementary compositions of the soils of Alcubillas allowed us to establish the pedogeochemical baseline levels and these are relevant because they allow the distinction of contaminated areas from uncontaminated ones. The absence of potentially polluting industrial activities in the area of study means that most of the potentially polluting chemical 

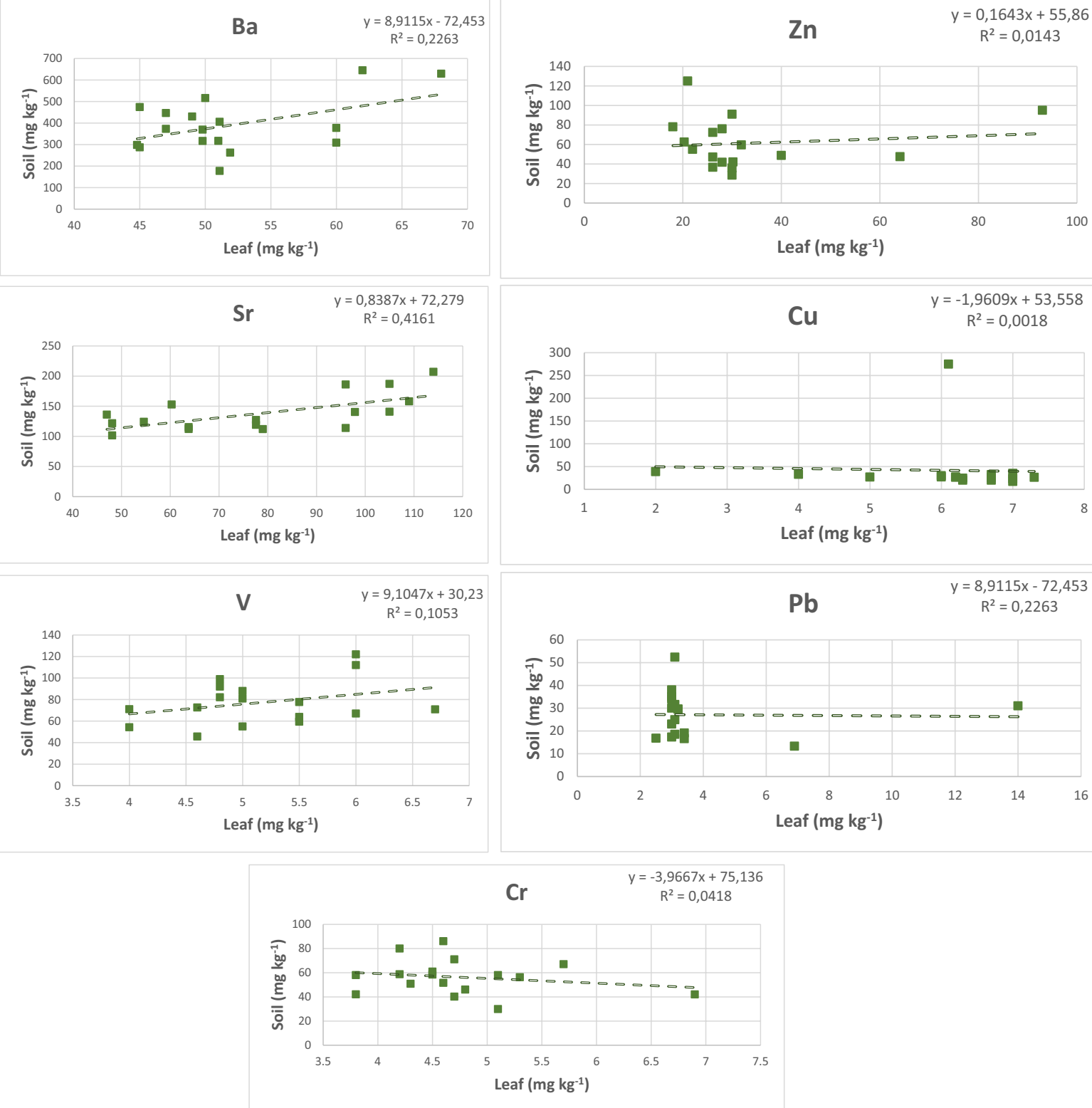

Fig. 2 Relationships between elemental contents in leaves and soils (BAC)

elements are at concentrations close to the pedogeochemical baseline levels of the region (Jiménez-Ballesta et al., 2010), i.e.^\#, they are directly associated with the existing lithological units or weathering processes.

It should be noted that the foliar application of fungicides or the addition (direct or irrigated) of phosphate fertilizers (with impurities that contain heavy metals such as $\mathrm{Cd}, \mathrm{Hg}$, and $\mathrm{Pb}$, Ramalho et al., 1999;
Nagajyoti et al., 2010) contributes to increased contents in soils, so it was expected that the vineyard soils of Alcubillas would have higher than normal contents in some PTEs. It is worth noting that $\mathrm{Cu}$ values have been reported for the soils of traditional wine regions throughout the world. For example, these values range from 20 to $500 \mathrm{mg} \mathrm{kg}^{-1} \mathrm{Cu}$ in France (Flores-Vélez et al., 1996; Brun et al., 1998), 35 to $600 \mathrm{mg} \mathrm{kg}^{-1}$ in Spain (Arias et al., 2004), 2 
to $375 \mathrm{mg} \mathrm{kg}^{-1}$ in Italy (Toselli et al., 2009), 100 to $210 \mathrm{mg} \mathrm{kg}^{-1}$ in Greece (Vavoulidou et al., 2005), and 40 to $250 \mathrm{mg} \mathrm{kg}^{-1}$ in Australia (Pietrzak \& Mcphail, 2004). This is not the case for Alcubillas, where the common feature is the addition of organic residues that are mainly of plant origin (pruning residues) to which goat and sheep excrement is added.

In Alcubillas, farmers are aware of this situation and they fertilize soils with only moderate doses with a low frequency of application. The farmers also control the changes that occur during the development and growth of the crop. In fact, even if the farmers are not aware of the origins, they observe structural, biochemical, and physiological changes through visible symptoms of phytotoxicity such as reduced growth (especially of the root system), chlorosis, and necrosis in the leaves.

On the basis of the $\mathrm{Cu}$ values found, one can expect shortening and thickening of the apex of the vine root (Ambrosini et al., 2015) along with an increase in the number of lateral roots and plasmolysis in the epidermis of some cells, thus reducing the density of the root hairs (Chen et al., 2013; Zhang et al., 2014). In addition, the presence of excess $\mathrm{Cu}$ in plant shoots can lead to a decrease in the concentration of photosynthetic pigments and the fixation rate of $\mathrm{C}$. These changes may in turn increase oxidative stress at the cellular level (Cambrollé et al., 2013). However, these symptoms were not observed in the studied area, because $\mathrm{Cu}$-fungicide applications are minimal to achieve the desired effects. The farmer is aware of this and avoids incorporating products that contain $\mathrm{Cu}$.

\section{Conclusions}

The vineyard soils display a heterogeneous concentration in terms of elemental composition in the study area, with Ca being one of the most abundant major elements and $\mathrm{S}$ below the average world background values. The small differences between the concentrations of the elements with depth can be explained by assuming a common source that is primarily geogenic and pedogenic in nature followed by secondary factors of ploughing and agricultural practices.

Regarding the pedogeochemical baseline levels, and despite the fact that the use of fertilizers and pesticides in the vineyard is common, we can describe the trace element contents as normal for the investigated area, that is, trace element values associated with potential toxicity in soils were not found. Indeed, a risk assessment of the elementary composition of the soils indicated that this does not currently pose a high risk and that there are no adverse effects caused by PTE accumulation in the soils. This is because the farmers are very sensitive to the environment and they aim to achieve only moderate yields of grapes per hectare.

The relationships between concentrations of elements in soil vs. leaves indicate that the higher soil contents in $\mathrm{Sr}, \mathrm{Pb}$, and $\mathrm{Cr}$ imply higher contents of these elements in the leaves, while the $\mathrm{V}$ content decreases in leaf as it increases in the soil. It was found that some elements were not taken up by the Vitis vinifera, even though elements like $\mathrm{Zr}$ and $\mathrm{Rb}$ are present in relatively high concentrations in the soil.

In conclusion, the present study provides a reference for future analogous studies in other areas, particularly in a Mediterranean environment, but additional research on trace element contents in grape clusters is required to understand better the transfer of trace elements from soil to products (grapes and wine).

Acknowledgements The authors are indebted to the Denominación de Origen Valdepeñas (Denomination of Origin), project number UCTR180065 for funding this project. Furthermore, the authors are also grateful to all farmers for the use of facilities during field work.

Funding Open Access funding provided thanks to the CRUE-CSIC agreement with Springer Nature.

Data Availability The datasets generated during and/or analyzed during the current study are available from the corresponding author on reasonable request.

\section{Declarations}

Conflict of Interest The authors declare no competing interests.

Open Access This article is licensed under a Creative Commons Attribution 4.0 International License, which permits use, sharing, adaptation, distribution and reproduction in any medium or format, as long as you give appropriate credit to the original author(s) and the source, provide a link to the Creative Commons licence, and indicate if changes were made. The images or other third party material in this article are included in the article's Creative Commons licence, unless indicated 
otherwise in a credit line to the material. If material is not included in the article's Creative Commons licence and your intended use is not permitted by statutory regulation or exceeds the permitted use, you will need to obtain permission directly from the copyright holder. To view a copy of this licence, visit http://creativecommons.org/licenses/by/4.0/.

\section{References}

Abdu, N., Agbenin, J. O., \& Buerkert, A. (2011). Geochemical assessment, distribution, and dynamics of trace elements in urban agricultural soils under long-term wastewater irrigation in Kano, northern Nigeria. Journal of Plant Nutrition and Soil Science, 174(3), 447-458. https://doi.org/10.1002/jpln.201000333

Adriano, D. C. (2001). Trace elements in terrestrial environments: Biogeochemistry, bioavailability, and risks of metals. Springer Verlag.

Alonso Gonzalez, P., \& Parga Dans, E. (2019). The return of terroir: The reawakening of wine in Spain. Rivar, 6, 7.

Amorós, J. A., García Navarro, F. J., Pérez de los Reyes, C., Campos, J. A., Bravo, S., Jiménez Ballesta, R., \& García Moreno, R. (2012). Geochemical influence of soil on leaf and grape (Vitis vinifera L. 'Cencibel') composition in La Mancha region (Spain). Vitis, 51(3), 111-118.

Amorós, J. A., Pérez de los Reyes, C., García Navarro, F. J., Bravo, S., Chacón, J. L., Martínez, J., \& Jiménez Ballesta, R. (2013). Bioaccumulation of mineral elements in grapevine varieties cultivated in "La Mancha". Journal of Plant Nutrition and Soil Science, 176(6), 843-850. https://doi. org/10.1002/jpln.201300015

Arias, M., López, E., Fernández, D., \& Soto, B. (2004). Copper distribution and dynamics in acid vineyard soils treated with copper-based fungicides. Soil Science, 169, 796-805.

Bello, A. O., Tawabini, B. S., Khalil, A. B., Boland, C. R., \& Saleh, T. A. (2018). Phytoremediation of cadmium-, leadand nickel-contaminated water by Phragmites australis in hydroponic systems. Ecological Engineering, 120, 126-133.

Beygi, M., \& Jalali, M. (2019). Assessment of trace elements $(\mathrm{Cd}, \mathrm{Cu}, \mathrm{Ni}, \mathrm{Zn})$ fractionation and bioavailability in vineyard soils from the Hamedan, Iran. Geoderma, 337, 10091020. https://doi.org/10.1016/j.geoderma.2018.11.009

Bloemen, M. L., Markert, B., \& Lieth, H. (1995). The distribution of $\mathrm{Cd}, \mathrm{Cu}, \mathrm{Pb}$ and $\mathrm{Zn}$ in topsoils of Osnabrück in relation to land use. Science Total Environment, 166, 137-148.

Bravo, S., Amorós, J. A., Pérez-De-Los-Reyes, C., García Navarro, F. J., Moreno, M. M., Sánchez-Ormeño, M., \& Higueras, P. (2017). Influence of the soil $\mathrm{pH}$ in the uptake and bioaccumulation of heavy metal ( $\mathrm{Fe}, \mathrm{Zn}, \mathrm{Cu}, \mathrm{Pb}$ and $\mathrm{Mn})$ and other elements ( $\mathrm{Ca}, \mathrm{K}, \mathrm{Al} \mathrm{Sr}$ and $\mathrm{Ba})$ in vine leaves, Castilla-La Mancha (Spain). Journal of Geochemical Exploration, 174, 79-83.

Brun, L. A., Maillet, J., Richarte, J., Hermann, P., \& Remy, J. C. (1998). Relationships between extractable copper, soil properties and copper uptake by wild plants in vineyard soils. Environmental Pollution, 102, 151-161.
Buccolieri, A., Buccolieri, G., \& Cardellicchio, N. (2006). Heavy metals in marine sediments of Taranto Gulf (Ionian Sea, Southern Italy). Marine Chemistry, 99, 227-235. https://doi.org/10.1016/j.marchem.2005.09.009

Burger, A., \& Lichtscheidl, I. (2019). Strontium in the environment: Review about reactions of plants towards stable and radioactive strontium isotopes. Science of the Total Environment, 653, 1458-1512. https://doi.org/10.1016/j.sciti tenv.2018.10.312

Cambrollé, L., García, J. L., Oocete, R., Figueroa, M. E., \& Cantos, M. (2013). Growth and photosynthetic responses to copper in wild grapevine. Chemosphere, 93, 294-301.

Chen, P. Y., Lee, Y. I., Chen, B. C., \& Juang, K. W. (2013). Effects of calcium on rhizotoxicity and the accumulation and translocation of copper by grapevines. Plant Physiology and Biochemistry, 73, 375-382.

Chen, H., Teng, Y., Lu, S., Wang, Y., \& Wang, J. (2015). Contamination features and health risk of soil heavy metals in China. Science of the Total Environment, 512-513(143), 153. https://doi.org/10.1016/j.scitotenv.2015.01.025

Chopin, E. I. B., Marin, B., Mkoungafoko, R., Rigaux, A., Hopgood, M., Delannoy, E., Cances, B., \& Laurain, M. (2008). Factors affecting distribution and mobility of trace elements $(\mathrm{Cu}, \mathrm{Pb}, \mathrm{Zn})$ in a perennial grapevine (Vitis vinifera L.) in the Champagne region of France. Environmental Pollution, 156, 1092-1098.

Conde, P., Martín Rubí, J. A., \& Jiménez Ballesta, R. (2008). Environmental evaluation of elemental cesium and strontium contents and their isotopic activity concentrations in different soils of La Mancha (Central Spain). Environmental Geology, 56(2), 327-334. https://doi.org/10.1007/ s00254-007-1168-x

Evans, J. L., \& Barabash, S. J. (2010). Molybdenum, silver, thallium and vanadium. In P. S. Hooda (Ed.), Trace elements in soils (1st ed., pp. 515-549). Wiley.

Fishel, F. M. (2014). Pesticide toxicity profile: Copper-based pesticides. University of Florida.

Flores-Vélez, L. M., Ducaroir, J., Jaunet, A. M., \& Robert, M. (1996). Study of the distribution of copper in an acid sandy vineyard soil by three different methods. European Journal of Soil Science, 47, 523-532.

Gallo, A., Zannoni, D., Valotto, G., Nadimi-Goki, M., \& Bini, C. (2018). Concentrations of potentially toxic elements and soil environmental quality evaluation of a typical Prosecco vineyard of the Veneto region (NE Italy). Journal of Soils and Sediments, 18(11), 3280-3289. https://doi.org/ 10.1007/s11368-018-1999-y

Geana, I., Iordache, A., Ionete, R., Marinescu, A., Ranca, A., \& Culea, M. (2013). Geographical origin identification of Romanian wines by ICP-MS elemental analysis. Food Chemistry, 138, 1125-1134.

Greenough, J. D., Mallory-Greenough, L. M., \& Fryer, B. J. (2005). Geology and wine 9: regional trace element fingerprinting of Canadian wines. Geoscience Canada, 32

Gu, Y. G., Gao, Y. P., \& Lin, Q. (2016). Contamination, bioaccessibility and human health risk of heavy metals in exposedlawn soils from 28 urban parks in southern China's largest city, Guangzhou. Applied Geochemistry, 67, 52-58. https://doi.org/10.1016/j.apgeochem.2016.02.004

Hooda, P. S. (2010). Trace elements in soils. Wiley. 
Huzum, R., Iancu, O. G., \& Buzgar, N. (2012). Geochemical distribution of selected trace elements in vineyard soils from the Huşi area, Romania. Carpathian Journal of Earth and Environmental Science, 7(3), 61-70.

IUSS Working Group WRB, (2015). World Reference Base for soil resources (2014), update 2015: International soil classification system for naming soils and creating legends for soil maps (World Soil Resources Reports No. 106). FAO, Rome

Jiménez-Ballesta, R., Conde, P., Martín, J. A., \& García, R. (2010). Pedo-geochemical baseline content levels and soil quality reference values of trace elements in soils from the Mediterranean (Castilla-La Mancha, Spain). Central European Journal of Geosciences, 2(4), 441-454.

Jiménez-Ballesta, R., García-Navarro, F. J., Bravo, S., Amoros, J. A., \& Pérez de los Reyes C. and Mejias M. (2017). Environmental assessment of potential toxic elements contents in the flooded floodplain area of Tablas de Daimiel wetland (Spain). Environ Geochem and Health, 39, 11591177. https://doi.org/10.1007/s10653-016-9884-3

Jiménez-Ballesta, R., Bravo, S., Amorós, J. A., Pérez-de los Reyes, C., García-Pradas, J., \& García-Navarro, F. J. (2020). Understanding the quality of local vineyard soils in distinct viticultural areas: A case study in Alcubillas (La Mancha, Central Spain). Agriculture, 10, 66. https:// doi.org/10.3390/agriculture10030066

John, K., Ayito, E. O., Akpan-Idiok, A. U., \& Efom, O. D. (2019). Status and distribution of soil available micronutrients along a hillslope at Ekpri Ibami in Akamkpa local government area of Cross River State, Nigeria. African Journal of Agricultural Research, 14, 40-45. https://doi.org/10.5897/AJAR2016.13634

Kabata-Pendias, A., \& Sadurski, W. (2004). Trace elements and compounds in soil. In E. Merian, M. Anke, M. Ihnat, \& M. Stoeppler (Eds.), Elements and their compounds in the environment (2nd ed., pp. 79-99). Wiley-VCH.

Kabata-Pendias, A., \& Szteke, B. (2015). Trace elements in abiotic and biotic environments. CRC Press.

Kment, P., Mihaljevic, M., Ettler, V., Sebek, O., Strnad, L., \& Rohlova, L. (2005). Differentiation of Czech wines using multielement composition. A comparison with vineyard soil. Food Chemistry, 91, 157-165. https://doi.org/10. 1016/j.foodchem.2004.06.010

Komárek, M., Čadková, E., Chrastný, V., Bordas, F., \& Bollinger, J. C. (2010). Contamination of vineyards soils with fungicides: A review of environmental and toxicological aspects. Environment International, 36, 138-151.

Liu, Z., Zhang, Q., Han, T., Ding, Y., Sun, J., Wang, F., \& Zhu, C. (2015). Heavy metal pollution in a soil-rice system in the Yangtze river region of China. International Journal of Environmental Research and Public Health, 13(1). https://doi.org/10.3390/ijerph13010063

Lugwisha, E. H. (2016). Heavy metal levels in soil, tomatoes and selected vegetables from Morogoro Region, Tanzania. International Journal of Environmental Monitoring and Analysis, 4(3), 82. https://doi.org/10.11648/j.ijema.20160 403.13

Luo, D., Zheng, H., Cheng, Y., Wang, G., \& Ding, F. (2010). Transfer characteristics of cobalt from soil to crops in the suburban areas of Fujian Province, Southeast China. Journal of Environmental Management, 91(11), 2248-2253.
Maltman, A. (2013). Minerality in wine: A geological perspective. Journal of Wine Research, 24, 169-181.

McBride, M. B. (1994). Environmental chemistry of soils. University Oxford Press.

Milićević, T., Relić, D., Urošević, M. A., Vuković, G., Škrivanj, S., Samson, R., \& Popović, A. (2018). Integrated approach to environmental pollution investigationSpatial and temporal patterns of potentially toxic elements and magnetic particles in vineyard through the entire grapevine season. Ecotoxicology and Environmental Safety Journal, 163, 245-254. https://doi.org/10.1016/j. ecoenv.2018.07.078

Mîrlean, N., Roisenberg, A., \& Chies, J. O. (2007). Metal contamination of vineyard soils in the wet subtropics (southern Brazil). Environmental Pollution, 149, 10-17.

Mishra, P., Singh, S. K., Srivastava, P. C., \& Singh, S. (2006). Distribution of molybdenum and boron in some soils of northern alluvial plain of UP and Uttaranchal in relation to soil characteristics. Agropedology, 16(1), 60-62.

Moreno, I. M., González-Weller, D., Gutierrez, V., Marino, M., Cameán, A. M., González, A. G., \& Hardisson, A. (2007). Differentiation of two Canary DO red wines according to their metal content from inductively coupled plasma optical emission spectrometry and graphite furnace atomic absorption spectrometry by using probabilistic neural networks. Talanta, 72, 263-268.

Muller, G. (1969). Index of geo-accumulation in sediments of the Rhine River. GeoJournal, 2, 108-118.

Nagajyoti, P. C., Lee, K. D., \& Sreekanth, T. V. M. (2010). Heavy metals, occurrence and toxicity for plants: A review. Environmental Chemistry Letters, 8, 199-216.

Peris, M., Micò, C., Recatalá, L., Sánchez, R., \& Sánchez, J. (2007). Heavy metal contents in horticular crops of a representative area of the European Mediterranean region. Science of the Total Environment, 378, 42-48.

Pessanha, S., Carvalho, M. L., Becker, M., \& Von Bohlen, A. (2010). Quantitative determination on heavy metals in different stages of wine production by total reflection X-ray fluorescence and energy dispersive X-ray fluorescence: Comparison on two vineyards. Spectrochimica Acta Part b: Atomic Spectroscopy, 65, 504-507.

Pham, N. T. H., Babcsányi, I., \& Farsang, A. (2021). Ecological risk and enrichment of potentially toxic elements in the soil and eroded sediment in an organic vineyard (Tokaj Nagy Hill, Hungary). Environmental Geochemistry and Health. https://doi.org/10.1007/s10653-021-01076-w

Pietrzak, U., \& Mcphail, D. C. (2004). Copper accumulation, distribution and fractionation in vineyard soils of Victoria, Australia. Geoderma, 122, 151-166.

Pohl, P. (2007). What do metals tell us about wine? Trends in Analytical Chemistry, 26, 941-949.

Protano, G., \& Rossi, S. (2014). Relationship between soil geochemistry and grape composition in Tuscany (Italy). Journal of Plant Nutrition and Soil Science, 177, 500-508.

Ramalho, J. F. G. P., Amaral Sobrinho, N. M. B., \& Velloso, A. C. X. (1999). Acúmulo de metais pesados em solos cultivados com cana de açúcar pelo uso contínuo de adubação fosfatada e água de irrigação. Revista Brasileira De Ciência Do Solo, 2, 971-979.

Reimann, C., \& Garrett, R. (2005). Geochemical backgroundconcept and reality. Science of the Total Environment, 
350, 12-27. https://doi.org/10.1016/j.scitotenv.2005.01. 047

Reis, A. P., Menezes de Almeida, L., Ferreira da Silva, E., Sousa, A. J., Patinha, C., \& Fonseca, E. C. (2007). Assessing the geochemical inherent quality of natural soils in the Douro river basin for grapevine cultivation using data analysis and geostatistics. Geoderma, 141, 370-383.

Rinklebe, J., Antoniadis, V., Shaheen, S. M., Rosche, O., \& Altermann, M. (2019). Health risk assessment of potentially toxic elements in soils along the Central Elbe River, Germany. Environment International, 126, 76-88.

Romic, M., \& Romic, D. (2003). Heavy metals distribution in agricultural topsoils in urban area. Environmental Geology, 43, 795-805. https://doi.org/10.1007/ s00254-002-0694-9

Schwarz, G., \& Belaidi, A. A. (2013). Molybdenum in human health and disease. Metal Ions in Life Sciences, 13, 415450. https://doi.org/10.1007/978-94-007-7500-8_13

Soil Survey Staff. (2014). Keys to soil taxonomy (12th ed.). Washington DC: USDA-Natural Resources. Soil Conservation Service.

Toselli, M., Baldi, E., Marcolini, G., Malaguti, D., Quartieri, M., Sorrenti, G., \& Marangoni, B. (2009). Response of potted grapevines to increasing soil copper concentration. Australian Journal of Grape and Wine Research, 15, 85-92.

Tóth, G., Hermann, T., Da Silva, M. R., \& Monatanarella, L. (2016). Heavy metals in agricultural soils of the European Union with implications for food safety. Environmental Pollution, 88, 299-309. https://doi.org/10.1016/j.envint. 2015.12.017

Ungureanu, T., Iancu, G. O., Pintilei, M., \& Chicoş, M. M. (2017). Spatial distribution and geochemistry of heavy metals in soils: A case study from the NE area of Vaslui county, Romania. Journal of Geochemical Exploration, 176, 20-32.

Vavoulidou, E., Avramides, E. J., Papadopoulos, P., Dimirkou, A., Charoulis, A., \& Konstantinidou-Doltsinis, S. (2005). Copper content in agricultural soils related to cropping systems in different regions of Greece. Communications in Soil Science and Plant Analysis, 36, 759-773.

Wightwick, A. M., Reichman, S. M., Menzies, N. W., \& Allinson, G. (2013). Industry wide risk assessment: A case study of $\mathrm{Cu}$ in Australian Vineyards Soils. Water Air and Soil Pollution, 224(1702), 1-8.

Zhang, L., Pan, Y., Lv, W., \& Xiong, Z. T. (2014). Physiological responses of biomass allocation, root architecture, and invertase activity to copper stress in young seedlings from two populations of Kummerowiastipulacea (maxim.) Makino. Ecotoxicology and Environmental Safety, 104, 278-284.

Zhou, L., Yang, B., Xue, N., Li, F., Seip, H. M., Cong, X., Yan, Y., Liu, B., Han, B., \& Li, H. (2014). Ecological risks and potential sources of heavy metals in agricultural soils from Huanghuai Plain. China. Environmental Science and Pollution Research, 21(2), 1360-1369. https://doi.org/10. 1007/s11356-013-2023-0

Publisher's Note Springer Nature remains neutral with regard to jurisdictional claims in published maps and institutional affiliations. 